\title{
Higher Intake of DK265 Corn Silage by Dairy Cattle
}

\author{
Y. Barrière, ${ }^{1}$ G. Dias Gonçalves, ${ }^{1, \star}$ J. C. Emile, ${ }^{1}$ and B. Lefèvre ${ }^{2}$ \\ ${ }^{1}$ Unité de Génétique et d'Amélioration des Plantes Fourragères, \\ INRA, 86600 Lusignan, France \\ ${ }^{2}$ RAGT Semences - R2N, Site de Bourran, BP 3357, \\ 12033 Rodez cedex 9, France
}

\begin{abstract}
In this experiment, intake of DK265 3-way corn hybrid by dairy cattle was compared specifically with intake 1) of its bm3 isogenic form, 2) of its 2 related singleway hybrids, and 3) of 2 controls that were registered hybrids of similar earliness. Both dry matter (DM) and lignin contents were similar in all hybrids except for the bm3 hybrid, which was less lignified. There was a tendency for lower starch content and, correlatively, higher neutral detergent fiber content in DK265 and in the 2 related single-way hybrids. Significant intake differences were observed between hybrids; the highest intake was recorded for the bm3 hybrid. Among normal hybrids, DK265 and one of its related single-way hybrids registered significantly higher intakes than other hybrids. Among normal hybrids, cell wall digestibility and/or lignin content did not explain all of the variations observed for intake, whereas the higher intake of DK265 bm3 could be related to its lower lignin content as compared with isogenic DK265. It was hypothesized that the higher intake observed for the DK265 hybrid was probably related to specific friability traits that are not relevantly measured through the usual tests used in corn breeding.
\end{abstract}

(Key words: corn silage, cell wall digestibility, lignin, bm3)

\section{INTRODUCTION}

Under European dairy cattle rearing conditions, whole-plant corn silage is the foundation of animal feeding and often constitutes $>75 \%$ of the animals' diet (DM basis). Genetic variation for silage corn digestibility values was established in numerous works from in vivo or in vitro measurements, either between regular hybrids or in comparison with bm3 hybrids (Barrière et

Received October 7, 2003.

Accepted December 16, 2003.

Corresponding author: Y. Barrière; E-mail: barriere@lusignan. inra.fr.

*Current address, Universidade Estadual de Maringua, Zootecnia, Maringa, Parana, Brazil. al., 2003). Genetic variation in silage corn efficiency for milk yield and quality was also proven in numerous comparisons between regular hybrids, between regular and bm3 hybrids, and between regular and leafy hybrids, despite the fact that in these latter experiments normal and leafy hybrids were not isogenic and, therefore, the higher milk yield could not definitely be related to the leafy trait (Barrière et al., 2003a). Voluntary intake is also a primary nutritional factor controlling animal production. Dairy cows consuming diets high in cell wall content are often unable to eat sufficient quantities of forage to meet their energy demands, in particular perennial grasses and alfalfa, but also forage with a high energy content such as whole-plant corn. However, very few works have been devoted to studies of genetic variation of intake related to corn plant genotypes in fixed environmental conditions. This is perhaps largely due to the great difficulty plant breeders have in working with cattle, leading to "a failure of most scientists to recognize the importance of voluntary intake, that has led to an unnecessary and undesirable gulf between the science and the practice" (Minson and Wilson, 1994). From feeding experiments devoted to corn genotype comparisons (Valentin et al., 1999; Barrière et al., 2003b), it appeared that the intake of corn hybrids of significantly lower whole-plant or cell wall digestibility was lower than the intake of hybrids of rather good cell digestibility. However, the results were not as clear when comparing hybrids of higher digestibility. Although it has been reported in a few experiments, some hybrids seem to have a higher intake by dairy cattle. A better intake was shown by Ciba-semences (1990, 1995; now Syngenta Seeds) in kindred hybrids Briard and Bahia. Intake was increased by 0.5 and $1.0 \mathrm{~kg} / \mathrm{d}$, respectively, compared with a commonly used hybrid of similar digestibility and earliness. However, the most demonstrative results showing evidence of genetic variation for intake in forage corn were obtained with the DK265 hybrid, which was registered in France in 1987. The voluntary intake of hybrid DK265, which is of good cell wall digestibility, was always greater than that of other hybrids, including hybrids with similar feeding value traits (Barrière et al., 1995, $2003 \mathrm{~b}$ ). When corn silage was given at about $75 \%$ of 
Table 1. Hybrids used in the experiments. (Dt1 and Dt2 are the two female dent lines, and Fl1 is the flint male line. All are involved in the 3-way hybrid DK265. Dt1bm3, Dt2bm3, and Fl1bm3 are the brown-midrib-3 isogenic forms of the corresponding lines.)

\begin{tabular}{lll}
\hline Hybrid & Formula & $\begin{array}{l}\text { Year of } \\
\text { registration }\end{array}$ \\
\hline DK265 & $($ Dt1 $\times$ Dt2 $) \times$ Fl1 & 1987 \\
DK265 bm3 & $($ Dt1bm3 $\times$ Dt2bm3 $) \times$ Fl1bm3 & - \\
HS1 & Dt1 $\times$ Fl1 & - \\
HS2 & Dt2 $\times$ Fl1 & - \\
Anjou285 & private & 1994 \\
Mexxal & private & 2001 \\
\hline
\end{tabular}

the diet, previous experiments proved that dairy cows fed a DK265 silage had an average intake reaching 1.3 $\mathrm{kg} / \mathrm{d}$ more than that of dairy cows fed hybrids with the same DM and grain contents and the same cell wall digestibility (Barrière et al., 1995, 2003b).

This work was devoted to a specific study with dairy cattle using the 3-way hybrid DK265 and 2 related single-way hybrids in comparison with 2 well-known registered hybrids as controls and with DK265 bm3. The objectives were 1) to investigate the potential variation in intake between DK265 and its 2 related singleway hybrids, 2) to investigate the potential variation in intake between DK265 and its bm3 isogenic hybrid, and 3) to give plant breeders information on the feasibility of breeding corn for specific traits related to intake.

\section{MATERIALS AND METHODS}

\section{Experimental Design and Treatments}

In this experiment, the DK265 3-way hybrid was compared specifically 1) to its 2 related single-way hybrids (HS1 and HS2), 2) to its bm3 isogenic form DK265 bm3, and 3) to 2 single-way, control-registered hybrids (Anjou285 and Mexxal) (Table 1). All of these hybrids are early flint $\times$ dent corn hybrids, except Mexxal, which has a nearly dent grain. Two hectares of each of the 6 corn hybrids were grown in 2002 at Institut National de Recherche Agronomique Lusignan (Vienne, France) in fields with homogeneous agronomic conditions. Row spacing was $0.75 \mathrm{~m}$, and density was 95,000 plants/ha. Irrigation was provided 3 times at $30 \mathrm{~mm}$ to prevent summer water stress. In mid September, the corn hybrids were harvested at the (hard) dough stage to yield silage with a DM content close to $30 \%$ using a machine without a grain cracker (John Deere 5730, Ormes, France) and then ensiled in bunker silos according to standard farming practices.

Chemical characteristics of the plants were estimated from 6 independent samples taken at harvest time. Samples were oven-dried $\left(65^{\circ} \mathrm{C}\right)$ and ground with a hammer mill to pass trough a $1-\mathrm{mm}$ screen. The NDF and acid detergent lignin contents were estimated according to Goering and Van Soest (1970). Starch and soluble carbohydrates were estimated according to Ewers method (EEC ISO 10520.2; Agence Française de Normalisation, 1981) and according to Lila (1977), respectively. These values were estimated using near infrared reflectance spectroscopy (NIRS system 6500 spectrophotometer) with wavelengths spaced every 4 $\mathrm{nm}$ from 1100 to $2500 \mathrm{~nm}$. Calibration equations were provided by SHB Libramont (Belgium). Validation of calibration regressions, coefficients of determination between laboratory analysis and predicted values, and standard errors of prediction were previously described in Roussel et al. (2002). The $\mathrm{NE}_{\mathrm{L}}$ value of forage corn for milk production in dairy cattle was estimated according to the French standards (Jarrige, 1988) and expressed as Unité Fourragère Lait (UFL), where 1 $\mathrm{UFL}=7.1 \mathrm{~mJ} / \mathrm{kg}$ of $\mathrm{DM}$. The $\mathrm{NE}_{\mathrm{L}}$ values and in vivo NDF digestibilities were predicted using new near infrared reflectance spectroscopy calibration developed at INRA Lusignan and based on $5 \mathrm{yr}$ of feeding value measurements with sheep (Barrière et al., 2003).

Six sets of 4 Prim'Holstein cows (1 primiparous and 3 multiparous) yielding about $8000 \mathrm{~kg}$ of milk/yr were used in these experiments. Cows were paired and were assigned to experimental diets according to parity, BW (average value $=599.5 \mathrm{~kg}$ ), date of calving (average value at the beginning of experiment $=51 \mathrm{~d}$ after date of calving), and milk yield during a 2 -wk pre-experimental period (average value $=30.1 \mathrm{~kg} / \mathrm{d}$ per cow). The feeding experiments were performed according to an incomplete balanced design (Table 2). Each set of cows was fed successively only 4 hybrids of the 6 tested hybrids during 4 periods. For each hybrid and each set of cows, measurements were performed for $10 \mathrm{~d}$ over $2 \mathrm{wk}$ after 2 wk of pre-experimental feeding with the involved hybrid. Cows were individually fed the experimental corn silage daily, ad libitum, in the morning using Calantype feeding doors for approximately $10 \%$ refusals. The diet of cows was balanced with two commercial concentrates (Table 3): a nitrogen-rich concentrate $(1.9 \mathrm{~kg}$, DM basis) and an energy-rich concentrate (average value $=3.1 \mathrm{~kg}$; range, 2.6 to $4.3 \mathrm{~kg}$, DM basis, according to the milk yield). Because sets of cows were balanced, quantities of concentrates were similar between sets (for each hybrid) during each of the experimental periods. Some wheat straw from the litter was also eaten by the cows (about $0.5 \mathrm{~kg} / \mathrm{d}$ per cow). Urea $(50 \mathrm{~g})$ and a premix of minerals and vitamins $(250 \mathrm{~g})$ were given in accordance with the usual requirements. The average forage:concentrate ratio was $76: 24$. The $\mathrm{NE}_{\mathrm{L}}$ values of the concentrates were given according to the value estimated by the purveyor (Centre Atlantique Aliments, Sceaux en Couhé, France). Usual characteristics of fer- 
Table 2. Experimental design used each year of the experiment ( 6 corn hybrids, 6 sets of cows, and 4 successive periods of experiments).

\begin{tabular}{lllllll}
\hline & \multicolumn{6}{c}{ Cow set } \\
\cline { 2 - 7 } Period & 1 & 2 & 3 & 4 & 5 & 6 \\
\hline 1 & DK265 & Mexxal & HS2 & HS1 & DK265 bm3 & Anjou285 \\
2 & DK265 bm3 & Anjou285 & DK265 & Mexxal & HS2 & HS1 \\
3 & HS1 & DK265 & Anjou285 & HS2 & Mexxal & DK265 bm3 \\
4 & Anjou285 & HS2 & Mexxal & DK265 bm3 & HS1 & DK265 \\
\hline
\end{tabular}

mented silage were estimated $\left(\mathrm{pH}, \mathrm{NH}_{3}\right.$ content, $\mathrm{VFA}$, and alcohol contents). These analyses were performed by a specialized laboratory (INZO, Château-Thierry, France).

\section{Statistical Analysis}

Basic data for analysis were elementary observations for each diet, period, cow, and day of experiment. Mean estimates and variance analyses were then computed according to the following statistical model:

$$
\begin{gathered}
\mathrm{Y}_{\mathrm{ijklh}}=\mu+\mathrm{P}_{\mathrm{i}}+\mathrm{P}_{\mathrm{i}} \times \mathrm{D}_{\mathrm{j}}+\mathrm{S}_{\mathrm{k}}+\mathrm{S}_{\mathrm{k}} \times \mathrm{C}_{1}+\mathrm{H}_{\mathrm{h}}+\mathrm{H}_{\mathrm{h}} \times \\
\mathrm{S}_{\mathrm{k}}+\mathrm{H}_{\mathrm{h}} \times \mathrm{S}_{\mathrm{k}} \times \mathrm{C}_{\mathrm{l}}+\varepsilon_{\mathrm{ijklh}}
\end{gathered}
$$

where

Table 3. Ingredient, chemical composition, and feeding value of concentrates fed to dairy cows

\begin{tabular}{llc}
\hline & $\begin{array}{l}\text { Nitrogen-rich } \\
\text { concentrate }^{1}\end{array}$ & $\begin{array}{c}\text { Energy-rich } \\
\text { concentrate }^{2}\end{array}$ \\
\hline Ingredient & & \\
Soybean cake, \% & 65 & 10 \\
Rapeseed cake, \% & 20 & 12 \\
Sunflower cake, \% & 15 & 7 \\
Wheat, barley, corn grains, \% & - & 41 \\
Wheat issues, \% & - & 21 \\
Soluble proteins, \% & - & 3 \\
Sugar beet molasses, \% & - & 3 \\
Mineral premix, g/kg & - & 5 \\
CaCO, g/kg & - & 20 \\
NaCl, g/kg & - & 5 \\
Chemical composition (DM basis) & & \\
OM, \% & 92.7 & 93.2 \\
CP, \% & 46.0 & 21.0 \\
Starch, \% & 2.5 & 32.0 \\
Crude fiber, \% & 12.9 & 9.2 \\
Fat, \% & 3.4 & 3.8 \\
Lysine, g/kg & 13.7 & 6.8 \\
Methionine, g/kg & 3.9 & 2.2 \\
P, g/kg & 8.3 & 7.4 \\
Ca, g/kg & 5.7 & 11.5 \\
Feeding value (DM basis) & & \\
NE, UFL ${ }^{3} / \mathrm{kg}$ & 1.09 & 1.05 \\
\hline
\end{tabular}

${ }^{1}$ Protival, Centre Atlantique Aliments, Sceaux en Couhé, France.

${ }^{2}$ Diapason, Centre Atlantique Aliments, Sceaux en Couhé, France.

${ }^{3} \mathrm{UFL}=\mathrm{NE}_{\mathrm{L}}$ unit according to the French standard $(1 \mathrm{UFL}=7.1$ $\mathrm{mJ} / \mathrm{kg}$ of DM).
$\mathrm{Y}_{\mathrm{ijlk}}=$ observed response,

$\mu=$ overall mean,

$\mathrm{P}_{\mathrm{i}}=$ period of experiment,

$\mathrm{P}_{\mathrm{i}} \times \mathrm{D}_{\mathrm{j}}=$ day of experiment nested in period effect,

$\mathrm{S}_{\mathrm{k}}=$ set of cows,

$\mathrm{S}_{\mathrm{k}} \times \mathrm{C}_{1}=$ cow nested in set of cows effect,

$\mathrm{H}_{\mathrm{h}}=$ hybrid effect,

$\mathrm{H}_{\mathrm{h}} \times \mathrm{S}_{\mathrm{k}}=$ hybrid $\times$ set of cows interaction effect, $\mathrm{H}_{\mathrm{h}} \times \mathrm{S}_{\mathrm{k}} \times \mathrm{C}_{\mathrm{l}}=$ hybrid $\times$ set of cows $\times$ cow nested in set of cows interaction effect, and

$\varepsilon_{\mathrm{ijklh}}=$ residual error .

Significance of hybrid effect was estimated as the $F$ ratio between hybrid mean square and hybrid $\times$ set of cows $\times$ cow nested in set of cows interaction mean square, because of the repeated measurement statistical design and according to Little and Hills (1978). The effect of variation of DM content on intake was also investigated by adding the DM content as a covariate in the variance analysis of the intake trait, which also led to the estimate of DM-adjusted means for each genotype. Detailed milk yield data will not be reported, as milk yield was measured in short periods and, thus, was considered insufficiently reliable.

\section{RESULTS}

Lignin contents were similar in all hybrids except for the bm3 hybrid, which was less lignified (Table 4). There was a tendency for lower starch content and, correlatively, higher NDF content in DK265 and in the 2 related single-way hybrids. Cell wall digestibility was highest in the bm 3 hybrid, lowest in the 2 control hybrids, and intermediate in the 3 hybrids related to DK265. Hybrids ranked similarly for $\mathrm{NE}_{\mathrm{L}}$ and $\mathrm{NDF}$ digestibility, but with lower differences in $\mathrm{NE}_{\mathrm{L}}$ than in NDF digestibility between control hybrids and DK265related hybrids. Silage preservation was suitable for all hybrids according to the usual parameters (Table 5). Silage DM contents equal to $31 \pm 2 \%$ were obtained for all hybrids, values fitting well with the feeding of dairy cows (Table 6). 
Table 4. Characteristics of hybrids at harvest.

\begin{tabular}{|c|c|c|c|c|c|c|}
\hline Hybrid & Starch & $\begin{array}{l}\text { Soluble } \\
\text { carbohydrates }\end{array}$ & $\mathrm{NDF}$ & $\mathrm{ADL}^{1} / \mathrm{NDF}$ & $\begin{array}{l}\text { NDF } \\
\text { Digestibility }\end{array}$ & $\mathrm{NE}_{\mathrm{L}}$ \\
\hline & - & $-(\%$ of $\mathrm{DM})$ & - & $(\%$ of $\mathrm{NDF})$ & $(\%)$ & $\left(\mathrm{UFL}^{2}\right)$ \\
\hline DK265 bm3 & 34.0 & 6.5 & 37.0 & 4.5 & 59.8 & 0.95 \\
\hline DK265 & 31.6 & 4.1 & 40.1 & 6.5 & 51.3 & 0.90 \\
\hline HS1 & 31.2 & 4.5 & 40.3 & 6.4 & 52.2 & 0.90 \\
\hline HS2 & 28.1 & 3.7 & 43.2 & 6.7 & 52.6 & 0.89 \\
\hline Anjou285 & 35.3 & 5.6 & 37.0 & 6.4 & 45.3 & 0.87 \\
\hline Mexxal & 34.7 & 4.1 & 39.3 & 6.4 & 45.9 & 0.86 \\
\hline Confidence limit & 2.5 & 0.9 & 2.0 & 0.2 & 1.0 & 0.01 \\
\hline
\end{tabular}

${ }^{1} \mathrm{ADL}=$ acid detergent lignin (Goering and Van Soest, 1970).

${ }^{2} \mathrm{UFL}=\mathrm{NE}_{\mathrm{L}}$ according to the French standard (1 UFL $=7.1 \mathrm{~mJ} / \mathrm{kg}$ of $\left.\mathrm{DM}\right)$.

The average milk yield during the experiment was $27.4 \mathrm{~kg} / \mathrm{d}$ per cow, ranging from 27.0 to $27.9 \mathrm{~kg} / \mathrm{d}$ for Anjou 285 and HS1, respectively, without significant differences between hybrids. The hybrid effect was highly significant for intake in dairy cows $(P<0.01$; Table 7), and this effect remained significant even when the bm3 hybrid was removed from the analysis. When DM content was added as a covariate, the hybrid effect for intake was only slightly increased, highlighting the importance of the genotypic effect over DM content in intake variations. Cows fed DK265 had a higher intake than cows fed the 2 control hybrids. Intake was also higher in cows fed DK265 or HS1 than in cows fed HS2 when considering DM-adjusted values. The DMadjusted intake of HS1 hybrid was also a little higher than the intake of DK265, but not significantly. The HS2 appeared similar to "normal" hybrid of rather good digestibility, but did not have the specific traits involved in specific higher intake. Cows fed the DK265 bm3 hybrid had intakes higher than cows fed DK265 by 1.1 $\mathrm{kg} / \mathrm{d}$ per cow, based on DM-adjusted data. Cows fed DK265 bm 3 also had higher intakes than cows fed HS1 by $0.6 \mathrm{~kg} / \mathrm{d}$. The specific determinant for higher intake of DK265 appeared different from the one involved in bm3 plants.

\section{DISCUSSION}

In this experiment, the highest intake was observed for cows fed the bm3 hybrid. The high nutritional value of such brown-midrib genotypes comes from both their high intake and digestibility. However, these favorable feeding traits are probably highly related to the significantly lower lignin content of these bm3 plants. However, a lower lignin content might have unfavorable consequences on plant standability, water or nutriment transport, and plant yield because of the possible collapsing of insufficiently lignified vessels. These negative effects are perhaps of greater importance in early genotypes than in latter ones, which are more lignified, more yielding, and often have a higher standability. Few bm3 late hybrids are available on the seed market in the US. These hybrids were proven to be very efficient in cattle feeding (Oba and Allen, 1999, 2000; Bal et al., 2000; Tine et al., 2000; Ballard et al., 2001). In Europe, the reputation of bm3 hybrids is still poor, and only limited investigations are performed for breeding bm3 silage corn. The choice of using corn silage of higher feeding value, but lower yield, is also a matter of strategy, not yet illustrated, and even more so in environmentally friendly conditions of agriculture management.

The higher intake observed for DK265 bm3 than for DK265 also indicated that the genetic (and molecular) determinants were not similar to the determinant of the high intake observed for the bm3 gene. Lignin content was indeed lower in DK265 bm3 than in DK265. Lignin content is not the reason why DK265 is a more ingestible hybrid. The flint Fl1 line is most likely to be

Table 5. Characteristics of fermented silages.

\begin{tabular}{|c|c|c|c|c|c|c|c|}
\hline & $\mathrm{pH}$ & $\mathrm{NH}_{3}$ & $\begin{array}{l}\text { Acetic } \\
\text { acid }\end{array}$ & $\begin{array}{l}\text { Lactic } \\
\text { acid }\end{array}$ & $\begin{array}{l}\text { Propionic } \\
\text { acid }\end{array}$ & $\begin{array}{l}\text { Butyric } \\
\text { acid }\end{array}$ & $\begin{array}{l}\text { Ethylic } \\
\text { alcohol }\end{array}$ \\
\hline & & & & & \multicolumn{3}{|c|}{$\mathrm{g} / \mathrm{kg}$ of $\mathrm{DM}$} \\
\hline DK265 bm3 & 4.0 & 8.4 & 15.7 & 57.3 & $<0.10$ & $<0.05$ & 6.9 \\
\hline DK265 & 4.0 & 8.5 & 19.3 & 74.6 & $<0.05$ & $<0.05$ & 5.6 \\
\hline HS1 & 3.9 & 6.9 & 13.9 & 65.9 & $<0.10$ & $<0.05$ & 6.7 \\
\hline HS2 & 4.0 & 8.4 & 13.9 & 53.7 & 0.48 & $<0.10$ & 4.9 \\
\hline Anjou 285 & 4.1 & 9.3 & 14.9 & 40.0 & 0.41 & $<0.10$ & 2.2 \\
\hline Mexxal & 4.1 & 9.1 & 16.4 & 52.6 & $<0.05$ & $<0.05$ & 5.3 \\
\hline
\end{tabular}


Table 6. Intake and DM mean values of hybrids (adjusted DM = $30.7 \%)$.

\begin{tabular}{lllc}
\hline & DM & Intake & $\begin{array}{l}\text { DM-adjusted } \\
\text { intake }\end{array}$ \\
\hline & $(\%)$ & & (kg/d per cow $)-$ \\
DK265 bm3 & 31.0 & 18.2 & 18.1 \\
DK265 & 30.4 & 16.9 & 17.0 \\
HS1 & 29.3 & 16.8 & 17.5 \\
HS2 & 31.0 & 15.6 & 15.4 \\
Anjou285 & 29.4 & 13.9 & 14.5 \\
Mexxal & 33.2 & 15.2 & 14.0 \\
Confidence limit & 0.4 & 0.7 & 0.6 \\
\hline
\end{tabular}

involved in the specific intake of DK265. Moreover, the higher intake value of DK265 also appeared related more to the Dt1 dent line than to the Dt2 dent line, with a possible specific combining ability effect in the cross Dt $1 \times$ Fl1.

The higher intake of DK265 and HS1 silages than of HS2 and control hybrids supported previous experiments involving the DK265 hybrid. In a 97-d experiment (Barrière et al., 1995), the intake of DK265 was $1.7 \mathrm{~kg} / \mathrm{d}$ higher than the intake of Rh162, which is of lower cell wall digestibility, but also $1.3 \mathrm{~kg} / \mathrm{d}$ higher than the intake of Brutus, which is of similar cell wall digestibility (DM and grain contents of silage were equal, and animals were fed equal quantities of concentrates for each hybrid). Cows fed Rh162 had a 1-kg/d lower milk yield than cows fed Brutus and DK265, but the average daily BW gain was 340 and $270 \mathrm{~g} / \mathrm{d}$ higher for cows fed DK265 than for cows fed Rh162 and Brutus, respectively. Similar results were observed in another 105-d experiment (Barrière et al., 1995) with reduced concentrate feeding to all animals. Intake of DK265 was 1.6 and $1.2 \mathrm{~kg} / \mathrm{d}$ higher than that of Rh162 and $\mathrm{Rh} 208$, respectively, which are of similar cell wall digestibility as DK265. Milk yield was 3.1 and $1.5 \mathrm{~kg} / \mathrm{d}$ per cow higher for cows fed DK265 than for cows fed the 2 control hybrids, respectively, all hybrids yielded similar BW gain, nearing 220 g/d per cow. Because intake of DK265 was higher than that of hybrids of similar cell wall digestibility (and grain content), cell wall digestibility could not be considered as the only genetic determinant in corn for intake in cows. Having been observed over $3 \mathrm{yr}$ and 11 corn hybrids, the NDF digestibility explained only $50 \%$ of the observed intake variation, and NDF digestibility was related more to intake than whole-plant digestibility or energy value (Barrière et al., 2003b). In this set of hybrids, which exhibited a very large range of NDF digestibility and intake values, the correlation between NDF digestibility and intake was logically higher, and NDF digestibility explained about 65 and $70 \%$ of the variation observed in intake, without and with the bm3 hybrid, respectively. However, when considering DK265, HS1, and HS2 in this experiment and DK265 and Brutus or DK265 and Rh208 in previous experiments, hybrids that were all of similar NDF digestibility, the higher intake of DK265 (and HS1) had to be explained by a trait other than NDF digestibility.

The regulation of the appetite of cows fed corn silage is considered, above all, a result of a physical regulation. Chemical and palatability traits are probably of very limited importance in properly prepared corn silage. Intake of forage is usually considered to be controlled by the time this forage is retained in the rumen (Minson and Wilson, 1994; Jung and Allen, 1995; Fernandez, 2003). Particles can escape from the bovine rumen to the digestive tract only when degraded to a size close to 2 to $4 \mathrm{~mm}$ (Andrieu and Baumont, 2000). Chewing during eating and ruminating is responsible for most of this particle breakdown in chopped forage (Minson and Wilson, 1994). Fernandez (2003) also observed that chewing during intake led to similar particulate size in bolus for 2 corn hybrids with differences in silage particle size and correlative differences in time spent eating

Table 7. Variance analysis for corn silage intake.

\begin{tabular}{|c|c|c|c|c|c|c|}
\hline & \multicolumn{3}{|c|}{ Without covariate } & \multicolumn{3}{|c|}{ With DM content as covariate } \\
\hline & $\mathrm{df}$ & $\begin{array}{l}\text { Mean } \\
\text { square }\end{array}$ & $F$ & $\mathrm{df}$ & $\begin{array}{l}\text { Mean } \\
\text { square }\end{array}$ & $F$ \\
\hline Period & 3 & 150.3 & $25.3^{* *}$ & 3 & 150.3 & $32.7 * *$ \\
\hline Day $\times$ period & 36 & 26.4 & $4.4^{* *}$ & 36 & 26.4 & $5.7 * *$ \\
\hline Set of cows & 5 & 82.7 & $13.9^{* *}$ & 5 & 82.7 & $18.0 * *$ \\
\hline Set of cows $\times$ cow & 18 & 355.8 & $59.8^{* *}$ & 18 & 355.8 & $77.3^{* *}$ \\
\hline DM content & - & - & - & 1 & 1029.0 & $223.5^{* *}$ \\
\hline Hybrid & 5 & 329.0 & $7.8^{* *}$ & 5 & 377.3 & $9.0 * *$ \\
\hline $\begin{array}{l}\text { Hybrid } \times \text { set of } \\
\text { cows } \\
\text { Hybrid } \times \text { set of }\end{array}$ & 10 & 77.9 & $13.1^{* * *}$ & 10 & 62.8 & $13.7 * *$ \\
\hline $\begin{array}{l}\text { Hybrid } \times \text { set of } \\
\text { cows } \times \text { cow }\end{array}$ & 54 & 42.1 & $7.1^{* *}$ & 54 & 42.1 & $9.1^{* *}$ \\
\hline Residual & 828 & 6.0 & - & 827 & 4.6 & - \\
\hline
\end{tabular}

$* * P<0.01$. 
per unit of feed intake. Ulyatt (1983) and Inoué et al. (1994), quoted in Fernandez (2003), had previously stated that food is chewed during eating to a common end point, so that the bolus may be easily swallowed. In tropical forages, McLeod et al. (1990) concluded that, "Voluntary intake was associated with the resistance of large particles to breakdown by chewing during both eating and ruminating." This conclusion was in agreement with works of Inoué et al. (1994), considering that both shear breaking load of tissue and plant morphology had to be considered for intake improvement in Lolium. As a consequence, from a plant breeder's standpoint, the intake and the filling capacity of corn forage or both probably depends upon genetic traits of the corn plant related to both its cell wall digestibility by rumen microorganisms and its mechanical resistance to chewing by cows, traits that should be considered as (partly) independent. Breeding forage corn for a higher cell wall digestibility allows improvement in energy feeding value and allows discard of hybrids with poor intake. However, specific higher intake, as it exists in DK265, and possibly Bahia or Briard, demands specific investigations for which no clear in vitro tests are available. Variations in degradation kinetic parameters that were measured in situ have been considered to be related to intake (Verbic et al., 1995; Tovar-Gomez et al., 1997; Valentin et al., 1999). Further works proved, in fact, that it was not possible to use this method on a great number of hybrids and samples, nor was it possible to establish relevant near infrared reflectance spectroscopy calibrations. Moreover, the in situ kinetic parameters were not sufficiently related to intake for their use as breeding traits (Andrieu and Baumont, 2000; INRA Lusignan, unpublished data). The main reason is very likely related to the prior grinding of samples investigated in fistulated cows, thus leading to the loss of mechanical characteristics of plant tissues likely involved in their friability. Furthermore, the search for highly ingestible corn will require a new investigation of old genetic resources that are not currently used, or that were never used, in corn breeding. This trait seems very uncommon in germplasm used in corn breeding. Because most forage corn hybrids are based on germplasm previously bred or also used in grain corn hybrid, it is very likely that such alleles that allow good friability of plants were eliminated during breeding for stalk standability and breakage resistance (on top of their unusual occurrence).

Lignin content is well known as the primary cause of reduced digestibility of plant cell walls. However, lignin structure (guaiacyl and syringyl monomer content released after thioacidolysis and syringyl:guaicyl ratio) and, in Poaceae (grasses), hydroxycinnamic acid contents (p-coumaric and ferulic acids) were also proven to have significant effects on cell wall digestibility (Méchin et al., 2000; Barrière et al., 2003a; Fontaine et al., 2003). However, until now, the effect of syringyl:guaiacyl ratio and the effect of $p$-coumaric or ferulic acid contents on corn intake were unknown. In poplar, the down-regulation of one laccase led to plants exhibiting no visible phenotype, but having reduced mechanical properties of the wood, which is probably a result of the highly altered xylem fiber cell walls (Ranocha et al., 2002). These transgenic plants had similar lignin content and syringyl:guaiacyl ratio as normal ones, but they accumulated soluble phenolics. This laccase was then considered involved in the formation of some phenoxy radicals, leading to cross-linking of xylem fibers. It could also be hypothesized that such down-regulated forage plants could be easier to degrade by ruminal microorganisms in cattle and then of higher intake. Targeted transgenesis in the lignin pathway, followed by intake measurements of plants by dairy cattle, may then be a relevant way for investigating specific corn genes involved in silage intake.

\section{CONCLUSIONS}

The high intake observed for the bm3 hybrid and the high nutritional value of such brown-midrib genotypes are highly related to the significantly lower lignin content of these bm3 plants and their correlative higher cell wall digestibility. Despite the fact that bm3 hybrids were proven very efficient in cattle feeding, they did not develop in the early corn silage market because of the agronomic negative effects of the bm3 mutation. Among normal hybrids, a higher specific intake was observed in DK265 and HS1 silages, which could not be explained only by differences in cell wall digestibility and/or lignin content. The flint line Fl1 and the dent line Dt1 are very likely involved in the specific higher intake of these two hybrids. Because voluntary intake is associated with the resistance of forage to breakdown by chewing during both eating and ruminating, it was hypothesized that the higher intake associated with this early corn germplasm was likely related to specific friability traits not yet understood, and not relevantly measured through the usual test used in the breeding of silage corn for an improved feeding value. Significant progress in understanding corn traits specifically related to intake by dairy cows will be based on the study of biochemical and molecular determinants of traits involved in cell wall biogenesis and growth of hybrids, comparatively in parental lines involved in DK265 and in lines of similar cell wall digestibility.

\section{ACKNOWLEDGMENT}

This work was partly funded by the French-German project "Eureka CEREQUAL." 


\section{REFERENCES}

Andrieu J., and R. Baumont. 2000. Digestibilité et ingestibilité du maïs fourrage, facteurs de variation et prevision. Fourrages 163:239-252.

Bal, M. A., R. D. Shaver, H. Al-Jobeile, J. G. Coors, and J. G. Lauer. 2000. Corn silage hybrid effects on intake, digestion, and milk production by dairy cows. J. Dairy Sci. 83:2849-2858.

Ballard C. S., E. D. Thomas, D. S. Tsang, P. Mandebvu, C. J. Sniffen, M. I. Endres, and M. P. Carter. 2001. Effect of corn silage hybrid on dry matter yield, nutrient composition, in vitro digestion, intake by dairy heifers, and milk production by dairy cows. J. Dairy Sci. 84:442-452.

Barrière Y., J. C. Emile, R. Traineau, and Y. Hébert. 1995. Genetic variation in the feeding efficiency of maize genotypes evaluated from experiments with dairy cows. Plant Breeding 114:144-148.

Barrière, Y., C. Guillet., D. Goffner, and M. Pichon. 2003a. Genetic variation and breeding strategies for improved cell wall digestibility in annual forage crops. A review. Anim. Res. 52:193-228.

Barrière Y., J. C. Emile, and F. Surault. 2003b. Genetic variation of silage maize ingestibility in dairy cattle 2003. Anim. Res. 52:489-500.

Ciba-semences, Valorisation laitière d'une variété de maïs en ensilage. 1990. Synthèse d'une expérimentation conduite par l'EDE de Vendée en 1988-89-90. Misc. Paper, 13 pp.

Ciba-semences, Comparaison de la valorisation par des vaches laitières de deux hybrides de maïs. 1995. Misc. Paper, 7 pp.

Fontaine, A. S., M. Briand, and Y. Barrière. 2003. Genetic variation and QTL mapping of para-coumaric and ferulic acid contents in maize stover at silage harvest. Maydica 48:75-84.

Fernandez, I. 2003. Influence de la finesse de hachage des ensilages de maïs sur leur digestion (amidon et parois) et leur ingestibilité par les vaches laitières, Thèse Université Blaise Pascal, Clermont-Ferrand, France.

Goering, H. K., and P. J. Van Soest. 1970. Forage Fiber Analysis (Apparatus, Reagents, Procedures, and Some Applications). Agric. Handbook No. 379. ARS-USDA, Washington, DC

Inoué T., I. M. Brookes, A. John, E. S. Kolver, and T. N. Barry. 1994. Effects of leaf shear breaking load on the feeding value of perennial ryegrass (Lolium perenne) for sheep. II. Effect on feed intake, particle breakdown, rumen digesta and animal performance. J. Agric. Sci. (Camb) 123:137-147.

Jarrige, R. 1988. Alimentation des bovins, ovins et caprins. Ouvrage collectif, INRA, ed.

Jung, H. G., and M. S. Allen. 1995. Characteristics of plant cell wall affecting intake and digestibility of forages by ruminants. J. Anim. Sci. 73:2774-2790.

Lila, M. 1977. Influence des modalités de séchage sur la mesure de la teneur des fourrages en éléments azotés et glucidiques.
Conséquences lors des récoltes d'essais au champ. Ann. Amélior. Plantes 27:465-475.

Little, T. M., and F. J. Hills. 1978. Subplot as repeated observations. Pages 125-137 in Agricultural Experimentation, Design and Analysis. John Wiley and Sons, New York.

McLeod, M. N., P. M. Kennedy, and D. J. Minson. 1990. Resistance of leaf and stem fractions of tropical forages to chewing and passage in cattle. Br. J. Nutr. 63:105-119.

Méchin, V., O. Argillier, Y. Barrière, I. Mila, B. Polet, and C. Lapierre. 2000. Relationships of cell-wall composition to in vitro cell-wall digestibility of maize inbred line stems. J. Sci. Food Agric. $80: 574-580$

Minson, D. J., and J. R. Wilson. 1994. Prediction of intake as an element of forage quality. Pages 533-563 in Forage Quality, Evaluation, and Utilization. G. C. Fahey, ed. Am. Soc. Agron., Inc., Madison, WI.

Oba, M., and M. S. Allen. 1999. Evaluation of the importance of the digestibility of neutral detergent fiber from forage. Effects on dry matter intake and milk yield of dairy cows. J. Dairy Sci. 82:589-596.

Oba, M., and M. S. Allen. 2000. Effect of brown midrib 3 mutation in corn silage on productivity of dairy cows fed two concentrations of dietary neutral detergent fiber. 1 . Feeding behavior and nutrient utilization. J. Dairy Sci., 83:1333-1341.

Ranocha, P., M. Chabannes, S. Chamayou, S. Danoun, A. Jauneau, A. M. Boudet, and D. Goffner. 2002. Laccase down-regulation causes alterations in phenolic metabolism and cell wall structure in poplar. Plant Physiol. 129:145-155.

Roussel, V., C. Gibelin, A. S. Fontaine, and Y. Barrière. 2002. Genetic analysis in recombinant inbred lines of early dent forage maize. II - QTL mapping for cell wall constituents and cell wall digestibility from per se value and top cross experiments. Maydica 47:9-20.

Tine, M. A., K. R. McLeod, R. A. Erdman, and R. L. Baldwin. 2000. Effects of brown midrib corn silage on the energy balance of dairy cattle. J. Dairy Sci. 84:885-895.

Tovar-Gomez, M. R., J. C. Emile, B. Michalet-Doreau, and Y. Barrière. 1997. In situ degradation kinetics of maize hybrid stalks. J. Sci. Food Agric. 68:77-88.

Ulyatt, M. J. 1983. Plant fibre and regulation of digestion in the ruminant. Pages 1-103 in Fibre in Human and Animal Nutrition. G. Wallace and L. Bell, ed. Massey Univ., New Zealand.

Valentin, S. F., J. M. Forbes, and P. Lescoat. 1999. Comparison of the voluntary intake by lactating cows of two maize silages with different in situ dry matter degradability. Ann. Zootechn. 48:211-218.

Verbic, J., J. M. A. Stekar, and M. Resnik-Cepon. 1995. Rumen degradation characteristics and fibre composition of various morphological parts of different maize hybrids and possible consequences in breeding. Anim. Feed Sci. Technol. 54:133-148. 